\title{
EMPLOYEES' COMPETENCE AND BUSINESS PERFORMANCE: A STUDY OF SELECTED HOTELS IN KEFFI
}

\author{
Salim Muhammad OGAJI \\ Department of Accounting and Business Administration, \\ Federal University Kashere, Gombe State-Nigeria \\ salimogajigmail.com
}

\begin{abstract}
Differential quality in services rendered by hotels at different occasions have left many customers unhappy and also not wanting to return to such hotels again. Since employees' performances translate to that of the firm, this study therefore sought to examine the effect of employees' competence on performance of selected hotels in Keffi. Five (5) hotels were purposively selected and a questionnaire were issued to a total of one hundred and five (105) employees of selected hotels. Date were analyzed using correlation and simple regression analysis with the aid of STATA13 software. The study found a positive relationship between competence and firms' performance. Also, the study found employees' competence to have positive and significant effect on performance of selected hotels and hence the study recommended that management of hotels should adopt the on-the-job training and also job rotation training methods so as to equip employees with required competence to perform at whichever unit they may find themselves.
\end{abstract}

Keywords: Competence, Performance, Hotel Services, On-the-job training.

\section{INTRODUCTION}

Numerous researches have indicated that competence is a collection of the related information, aptitudes attributes and mentalities that associates with viable presentation and can be estimated assessed, and improved through advancement programs. It is considered as a typical term for employees to state their working and demonstrate the genuine exercises (Berger and Udell, 2002).

The changes witnessed by firms both internally and externally are adduced to the level of contributions that its human resources make which indicates that the existence of human resources in a company can be one of the drivers of the company's performance. According to Donatus et al. (2018), the most crucial element affecting the accomplishment of one's work is the competence factor of the individual concerned. Competence is therefore described as basic characteristics, personality which deeply rooted in an 
individual and influence the behaviour of a worker when he faces the job which are capable of affecting the effectiveness of the job at hand.

Despite the huge financial investment in the hospitality industry precisely the hotel segment of the industry which suggest the availability of financial resources capable of promoting firms to advantageous positions in terms of innovation adaptability as well as improved services, customers continue to witness differential quality of services offered by same hotels at different occasions which has overtime left customers dissatisfied with some never wanting to return back to same hotels. This situation has led to shortfall in terms of number of customers as well as the amount of profit the hotels make.

As clearly posited by Gungor (2011), that firms almost completely are dependent on their employees' performance to translate to organizational performance, it is very much apparent that level of individual employees' performance which is reliant on the skill and competence of such individual, adds to overall performance of such firms. Based on the foregoing it becomes imperative for the hotel management to uncover the effect of employees' competencies on their performance and hence this study.

\section{Research Questions}

How does employees' competence affect the performance of selected hotels in Keffi?

\section{Hypothesis of the Study}

Ho1: Employees' competence has no significant effect on the performance of selected hotels in Keffi.

\section{LITERATURE REVIEW}

\subsection{Concept of Competence}

Zaim et al. (2013) defined competence as a characteristic trait of a person or group that is related to superior performance and a demonstration of particular talents in practice and application of knowledge required to perform a job. Also, Renyut et al. (2017) defined competence as the ability to execute or perform a job or task that is based on skills and knowledge and is supported by the work attitude demanded by the job.

Basically, the words skills, expertise, acumen, competency, qualities and/or values are used interchangeably in literatures which signifies quality of performance which depends not only on individual natural ability, but also on training, practice and experience (Adeyemo, 2009; Rudmann, 2008; Smith and Morse, 2005; Hamzat et al., 2018). Training and development are a continuous effort designed to improve employees' competence and organize performance as a goal to improve on the employees' capacity and performance (Enga, 2017). 
Competence has been said to be showing the characteristics of knowledge and skills that individuals have or need to enable them to perform their duties and responsibilities effectively and to raise the professional quality standards in their work. Also, its seen as the ability that must be owned by an employee or to perform a job with maximum (effective, efficient, productive and qualified) in accordance with the targeted organization/leader (Donatus et al. 2018).

Wibowo (2010) also defined competence as the ability to perform a job or task based on skills and knowledge and supported by the work attitude demanded by the job. Competence includes a set of intelligent actions, full of responsibilities that someone has as a condition to be considered capable by the community in carrying out tasks in the field of work. Similarly, researchers argued that employees' performance depends on many factors of which training is the most important and which enhances the capabilities of employees. They further stated that employees with higher on-the-job experience have better performance because there is an increase in the both skills and competencies.

Competence refers to the underlying attributes of a person in terms of motive, trait, skill, aspect of one's image, social role, or a body of knowledge which he or she offers for use (Boyatzis, 2000). It is also defined as a bundle of affiliated skills, knowledge and attitude that has significant effect on one's job as well as performance on the job which is measured against acceptable standards and is subject to improvement through training and development (Adomi, 2006).

Owoeye and Muathe (2018) also defined competence as true applied knowledge and utilized capacity of an individual or an organization. Furthermore, competence can be defined as a bundle of skills, knowledge, and attributes that affects the job a person does. It is seen to have a correlation with performance which can be measured on a particular standard and has likelihood of improvement (Özçelik and Ferman, 2006). From the forgoing, this study defines competence as the attributes, skills, knowledge and expertise required by an employee or organization in general to execute a set of given activities as it relates to the overall organizational goals and objectives.

\subsection{Concept of Performance}

According to Nwaiwu and Aliyu (2018), performance is described as relating to the realization of firm's goals and objectives with minimum resources. An appropriate firm performance assessment affords its manager the understanding of the status of the organization. Performance according to Gharakhani and Mousakhani (2012), refers to the ability of an organization to create outcomes and actions at a desired and acceptable level. Additionally, Ramayah et al. (2011), opined that organizational performance directly points to the degree that an organization attain its own needs and that of its stakeholder so as to survive. 
Similarly, Ho (2011), referred to performance as a measure of how well an organization achieves its objectives. Performance has been defined as the ability of a firm to accomplish its goals and objectives with the help of talented administration, good governance backed by a constant rededication to accomplish business objectives (Mahapatro, 2013). Also, it has been defined as the achievement made by various divisions within an organization, with a specific timeframe to achieve the overall goals and targets at different stages.

Measurement of performance in organizations can be performed using various objectives and measurements (Abu-Jarad et al., 2010; Corboș et al., 2017). Many studies however, lay more emphasis in terms of measuring organizational performance on the financial measures which is inadequate, as such non-financial measures ought to be used (Tseng, 2010). As argued by Gruian (2011), financial performance is a result of operational performance; therefore, without operational performance financial performance would not exist. Further, Clarke et al. (2011) proposed four dimensions for measuring organizational performance which include: return on assets, return on equity, growth, and employee productivity.

From the operational point of view, performance encompasses all progress related to organizations internal operation, such as productivity, product quality and customer satisfactions (Feng et al., 2008). Similarly, Manikas and Terry (2010) referred to operational performance as the ability to measure the outcomes of an organization's processes. Furthermore, operational performance was coined to mean the non-economic aspects of an organization's social and societal relationships and competitive success factors that influence the efficiency of its operations (Luo et al., 2012).

In addition, Peng et al. (2011), opined that operational performance is usually measured using five dimensions: cost, quality, delivery, flexibility and innovation. These non-financial measures are so popular because they are used as a means for transferring a firm's strategy and vision into a tool that influences performance and leads to superior financial performance (Fullerton and Wempe, 2009). Therefore, performance is defined as the ability of firm to meet up with set goals and objectives as well as its ability to improve on the attained feats in relation to financial and operational dimensions such as growth, product quality, profit margin, increased shareholder's wealth, customers' satisfaction and cost minimization (Carstea et al., 2017). It may also be seen as the difference between actual results and expected outcomes in terms of finance, market share, production output, sales volume.

\subsection{Empirical Studies}

Chigozie et al. (2018) evaluated the effect of human capital development on organizational performance in manufacturing industries in South-East Nigeria. Using the survey method, questionnaires were 
administered to 358 respondents. Regression was employed to test the hypotheses which revealed human capital development significantly improves employees' competence which in turn enhances organizational productivity. Similarly, Donatus et al. (2018) analyzed the influence of competence and motivation on employee performance simultaneously with the influence of competence and motivation on the ability of employees using a sample of 40 employees at PT BinaSinar Amity. Simple random sampling was employed to select the sample. Questionnaires were distributed, retrieved and analyzed via regression analysis. The results revealed that competence and motivation have a positive effect on employee performance. The direct impact of competence on employee performance is 0.398 , while the influence of indirect competence on employee performance through the ability that was equal to 0.491 . Also, Mulwa and Weru (2017) in their study on the influence of performance management system on employee performance in commercial banks in Kitui county Kenya concluded from the responses obtained through questionnaire from a sample of 94 respondents that performance management significantly improves staff competence which in turn translate to improved organizational performance. The study also suffered the generalization problem as though respondents were drawn from just a few banks. Likewise, Yang et al. (2017) set out to determine the mediating role of competency (professional competency, technical competency, and core competency) between training and task performance in pharmacists in Taiwan. Questionnaire were distributed to a sample of (210) pharmacists. The results of the study indicated that there is a positive effect of training on task performance. Also, there is full effect of the two mediator variables (professional competency; technical competency) and partial effect of the one mediator variable (core competency) on the relationship between independent and dependent variables.

Nikolajevaite and Sabaityte, (2016) examined the relationship between employee competencies and job satisfaction among two-target groups-British and Lithuanian employees. Questionnaires were employed to obtain data from a sample of 67 employees from the two target groups. Correlation analysis was employed to test the relationship between employees' competence and job satisfaction of which the results revealed a positive and significant correlation between the two constructs. Also, Panda and Jayarama (2016) studied the impact of employees' competence on organizational effectiveness in India. Data were obtained from a sample 850 respondents with the aid of a questionnaire. Simple regression with the aid of SPSS was employed to test the hypothesis formulated. The research found a significant and positive effect of competence on organizational effectiveness in India.

Owoeye and Muathe (2018), investigated theoretically competence-enhancing interventions and organisational performance. drawing its conclusion from relevant theories and literatures, the study concluded that employees' commitment mediates between competence and organizational performance and also that competence in its overall affect positively organizational performance. The study wasn't 
premised on a strong and reliable tool of analysis. In another development, Sarminah (2013) investigated the relationship between human capital and business performance. Data were collected from a sample of 390 managerial staff in Malaysian logistics companies based on stratified random sampling. Regression was applied to analyze data which revealed that human capital aspects of employees' competence and creativity are related and contributes significantly to business performance.

Similarly, Zaim et al. (2013) analyzed the effects of individual competencies on performance of services industries in Turkey. Using a survey research design, questionnaires were distributed to 2679 employees in 30 companies. An exploratory factor analysis (EFA) was used to analyze the data obtained. The findings revealed that there is a positive relationship between competencies and individual performance and also individual competence affects positively on organizational performance. Likewise, Osei and Ackah (2015) examined the relationship between employees' competence and firm's performance among pharmaceutical firms in Ghana employing the use of questionnaires to obtain data from 280 respondents. Linear regression analysis indicated a strong, significant and positive effect of employees' competence and firm's performance.

Also, Jabbouri and Zahari (2014) studied the impact of core competences on organizational performance in Iraqi private banking sector. Using questionnaire data were collected 200 managers in these banks. Regression analysis was employed and the study revealed that core competences significantly affects organizational performance and also augments customer's satisfaction. Also, Renyut et al. (2017) explored the influence of organizational commitment, competence to employee performance at the Maluku Governor's office, Indonesia involving 244 respondents. The WarpPLS results indicates that employee competence indirectly has a positive and significant effect on employee performance as mediated by job satisfaction.

Hartonoa et al. (2017) analyzed the relationship between lecturers' performance and their teaching competence, measured by organizational learning and need for achievement. Random sampling method was employed to collect data from 207 lecturers of private universities in Central Java, Indonesia. Structural Equation Mode was employed for analysis and the study showed a positive significant relationship between the lecturers' competence and performance and also that teaching competence strongly mediates the relationship between organizational learning and performance.

\subsection{Knowledge-Based View (KBV)}

The knowledge-based view of the firm sees knowledge as the most crucial strategic resource for achieving competitive advantages (Zamfir, 2013) and in this regard the theory is viewed as an extension 
of the resource-based view of the firm (De Carolis, 2002). Scholars such as Garud and Kumaraswamy (2002); Grant (2002) and Mathews (2003) confirmed that the KBV is in line with current economic context where competition is ever increasing and intangible asset are highly valued. KBV theory considers knowledge as the most strategic organizational source of competence. The theory also confirmed further that knowledge-related resources contributes higher value for achieving organizational performance than tangible resources. Similarly, the KBV of the firm addresses issues relating to the presence, the limits and the internal organization of the multi-person firm (Foss, 1996). Foss (2005) believed that knowledge is the key factor in explaining and enhancing organizational competences.

Valmohammadi and Ahmadi (2015), postulated that the procedures engaged in managing knowledge resident in employees which entails managers' ability to integrate such individual owned knowledge through the provision of structural arrangements of co-ordination and cooperation among specialized knowledge workers lead to an increase in organizational performance.

Proponents of the KBV such as Barkat and Beh (2018); Andreeva and Garanina (2017) and Kurfi et al. (2017), accentuated that knowledge resources are heterogeneous, complex, immobile and difficult to replicate by competitors and as such are the core source of competitive advantage. They put forward that the most important elements of the KBV are: the existence of knowledge as the more useful resources which causes a difference in performance between firms; knowledge embedded in individuals are stored and converted into competitive advantage; the existence of knowledge in the form of individuals, organizational routines and databases as well as externalized in the form of relationships; also that knowledge cannot be fully exploited and managed as other forms of resources. The significance of this theory to this study is that it takes into consideration all cost associated with the development of employees as investments geared towards improving the productive competencies of individual workers which in turn creates competitive advantage of which the resultant effect is improved organizations performance.

\section{METHODOLOGY}

The study adopted the cross-sectional research design employing a survey method. Simple regression analysis with the aid of STATA13 software was employed to analyze the responses from the primary data collected from a sample of one hundred and five (105) employees of five hotels namely: Sawalino, Minki Suites, Crystal, Kingpin and New Keffi hotel. The hotels were purposively selected based on availability of modern lodging facilities. Well-structured closed ended questionnaires of 5-points likert scale were administered to the selected employees of selected hotels in Keffi. The questionnaire was 
tested for reliability using Cronbach alpha. The two variables indicated a combined alpha of 0.95 which is higher than the 0.6 minimum value as recommended by Sekaran (2006).

\subsection{Model Specification}

The model for the simple regression analysis is specified below:

$\mathrm{PER}=[0+[1 \mathrm{ECP}+\mathrm{e}$

Where:

PER $=$ Performance, ECP $=$ Employees' Competence, $[0=$ Intercept, $11=$ Coefficient of Independent Variable, $\mathrm{e}=$ error term.

\section{RESULTS AND DISCUSSION}

TABLE 1. DESCRIPTIVE STATISTICS
\begin{tabular}{|c|c|c|}
\hline stats & per & ecp \\
\hline mean & 3.619 & 3.628 \\
\hline sd & 1.013 & 1.049 \\
\hline max & 5 & 5 \\
\hline min & 1 & 1 \\
\hline skewness & -.354 & -.618 \\
\hline Source: STATA Output, 2019
\end{tabular}

Table 1 shows the descriptive statistics which explains the behavior of the variables under study. Employees' competence (ECP) had a mean of 3.619 and a standard deviation value of 1.013 as well as 
Table 2 revealed the extent to which the variables under study relate with each other. The finding indicated the presence of a strong and positive relationship to the tune of 0.89 between employees' competence (ECP) and performance (PER) which is significant at $1 \%$ level of significance.

TABLE 3. REGRESSION ANALYSIS

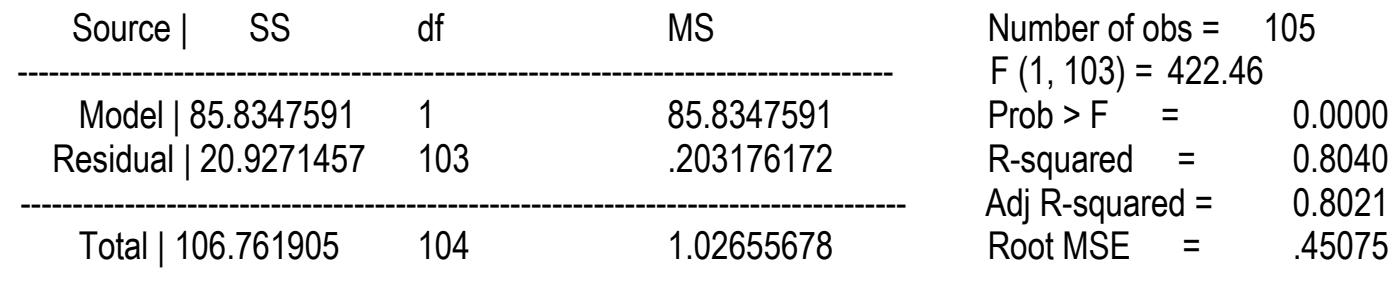

\begin{tabular}{|c|c|c|c|c|}
\hline per $\mid$ & Coef. & Std. Err. & $t$ & [95\% Conf. Interval] \\
\hline ecp | & .8657685 & .0421218 & 20.55 & $\begin{array}{lll}0.000 & .7822299 & .949307\end{array}$ \\
\hline _cons | & .4775449 & .159046 & $3.00 \quad 0.003$ & $.1621146 \quad .7929752$ \\
\hline
\end{tabular}

Source: STATA Output, 2019

The result, as shown in Table 3 revealed an R-square value of 0.8040 which implies that $80 \%$ of the variation in performance (PER) is explained by employees' competence (ECP). The remaining $20 \%$ variation could be explained by other factors not included in this study. The f-statistics value stood at 422.46 with a probability value of 0.0000 which is significant at $5 \%$ level of significance $(p \quad 0.000<0.05)$ which therefore, indicates that the model is fit to measure the association between the variables under study.

The regression line PER $=0.4775+0.8658 \mathrm{ECP}$ indicates that a unit increase in employees' competence $(E C P)$ will lead to a 0.8658 increase in the value of performance (PER) with statistical significance. The probability of t-statistics stood at 0.00 which is less than 0.05 level of significance and as such the study rejects the null hypothesis and accept the alternative hypothesis which states that employees' competence has significant effect on performance of selected hotels in Keffi.

\section{DISCUSSION OF FINDINGS}

This study examined the effect of employees' competence on the performance of selected hotels in Keffi, Nasarawa State. The findings from the hypothesis tested revealed that employees' competence significantly and positively affects performance of selected hotels. This implies that the higher the level of competence employees possesses, the better the performances of the organization. This finding is in conformity with that of Osei and Ackah (2015) who a positive effect of competence on performance of 
pharmaceutical firms in Ghana and also the findings of Zaim et al. (2013) and Owoeye and Muathe (2018), who found positive effect of competence on performance of firms.

\subsection{Conclusion and Recommendations}

Drawing inference from the above finding, the study concludes that employees' competence significantly impacts on performance of firms and therefore, firms with highly skilled and competent employees will perform better than those without in terms of better service delivery as well as improved performance. As a result, the study recommends that the management of hotels should adopt training methods of on-the-job training and job rotation so as to develop employees and equip them with needed competence to perform excellently in whatever position they find themselves.

\subsection{Limitation of the Study}

The study just like every other study suffers from some limitations. Of the limitations faced by this study is its lack of general applicability as though it was carried only using selected hotels in Keffi. The study didn't take into consideration other factors that could affect performance such as managerial competence and organizational culture.

\section{REFERENCES}

Abu-Jarad, I., Yusof, N. \& Nikbin, D. (2010) A Review Paper on Organizational Culture and Organizational Performance. International Journal of Business and Social Science, 1(3), 26-46.

Adeyemo, S. A. (2009). Understanding and acquisition of entrepreneurial skills: A pedagogical reorientation for classroom teacher in science education. Journal of Turkish Science Education, 6(3), 57-65.

Adomi, E. E. (2006). Job rotation in Nigerian university libraries. Library Review, 55(1), 66-74.

Andreeva T. \& Garanina T. (2017) Intellectual Capital and Its Impact on the Financial Performance of Russian Manufacturing Companies. Foresight and STI Governance, 11(1), 31-40. DOI: 10.17323/2500-2597.2017.1.31.40.

Barkat, W. \& Beh, L., (2018). Impact of Intellectual Capital on Organizational Performance: Evidence from a Developing Country. Academy of Strategic Management Journal. Volume 17, Issue 2, 19396104-17-2-203.

Berger, A., \& Udell, G. (2002). Relationship Lending and Lines of Credit in Small Firm Finance. Journal of Business, 68 (3), 351-381

Boyatzis, C. J. (2000). The artistic evolution of Mommy: A longitudinal case study of symbolic and social processes. New directions for child and adolescent development, 2000(90), 5-29.

Carstea, G., Corbos, R. A., Popescu, R. I., \& Bunea, O. I. (2017). Analysis of the influence of some indicators on the profitability of the FMCG retail market in Romania. In Proceedings of the 11th 
International Management Conference "The Role of Management in the Economic Paradigm of the XXI Century ", November 2nd-4th, Bucharest, Romania (pp. 481-492).

Chigozie, M. P., AGA, C. C., \& Onyia, E. (2018). Effect of Human Capital Development in Organizational Performance in Manufacturing Industries in South-East Nigeria. International Journal of Academic Research in Economics and Management Sciences, 7(3), 60-78. DOI: 10.6007/IJAREMS/v7-i3/4378

Clarke, M., Seng, D., \& Whiting, R. H. (2011). Intellectual capital and firm performance in Australia. Journal of Intellectual Capital, 12(4), 505-530. https://doi.org/10.1108/14691931111181706.

Corboș. R.A., Popescu, R. I., \& Bunea, O. I. (2017). Strategic Implications of Analyzing Competitiveness Measuring Instruments for Romania. Business Excellence and Management, 7(2), 13-26.

De Carolis, D. (2002). The Role of Social Capital and Organizational Knowledge in Enhancing Entrepreneurial Opportunities in High-Technology Environments. In Choo and Bontis (Eds.). The Strategic Management of Intellectual Capital and Organizational Knowledge, New York: Oxford University Press, 699-709.

Donatus, A.K., Guswandi, \& Akhmad, S. (2018). The effect of competence and motivation on employee performance through employees' capabilities on Pt. Binasinar Amity. International Journal of Research Science \& Management. 6. (37). DOI: 10.5281/zenodo.1249804.

Enga, E. (2017). The impact of training and development on organizational performance. (Postgraduate Thesis). Centria University of Applied Sciences.

Feng, M., Terziovski, M. \& Samson, D. (2008). Relationship of Quality System Certification with Operational and Business Performance. Journal of Manufacturing Technology Management. Vol. 19, 22-37. https://doi.org/10.1108/17410380810843435.

Foss, N. (1996). Knowledge-based approaches to the theory of the firm: Some critical comments. Organization Science, 7(5), 470-476.

Foss, N. (2005). Strategy, economic organization and the knowledge economy, The Coordination of firms and resources. Oxford University Press, Oxford

Fullerton, R. \& Wempe, W. (2009). Lean Manufacturing, Non-Financial Performance Measures, and Financial Performance. International Journal of Operations \& Production Management. 29(3), 214240. https://doi.org/10.1108/01443570910938970

Garud, R. \& Kumaraswamy, A. (2002). Technological and Organizational Designs for Realizing Economies of Substitution. In Choo and Bontis (Eds.) the Strategic Management of Intellectual Capital and Organizational Knowledge, New York: Oxford University Press, 233-253.

Gharakhani, D. \& Mousakhani, M. (2012) Knowledge Management Capabilities and SMEs' Organizational Performance. Journal of Chinese Entrepreneurship. Vol. 4. 35-49. https://doi.org/10.1108/17561391211200920

Grant, R. (2002). The Knowledge-Based View of the Firm. In Choo and Bontis (Eds.) the Strategic Management of Intellectual Capital and Organizational Knowledge, New York: Oxford University Press, 133-148.

Gruian, C. (2011). The Influence of Intellectual Capital on Romanian Companies' Financial Performance. Annales Universitatis Apulensis Series Oeconomica. Vol.13, 260-272.

Gungor, P. (2011). The Relationship between Reward Management System and Performance. Procedia Social and Behavioral Sciences, 1510-1520. Retrieved from http:// www.sciencedirect.com 
Hamzat, B.S., Bello, B.A., Opele, A.M. (2018). Compensation, Employee Performance and Organization Performance in Guarantee Trust Bank (Gt Bank) Plc. Business Excellence and Management, 8(4), 14-28.

Hartonoa, E., Wahyudi S., Harahap, P. \& Yuniawan, A. (2017). Does Organizational Learning Affect the Performance of Higher Education Lecturers in Indonesia? The Mediating Role of Teaching Competence. International Journal of Environmental \& Science Education. VOL. 12, NO. 4, pp. 865878

Ho, L. (2011) Meditation, Learning, Organizational Innovation and Performance. Industrial Management \& Data Systems. Vol. 111, 113-131. https://doi.org/10.1108/02635571111099758

Jabbouri, N.I. \& Zahari, I. (2014). The role of core competencies on organizational performance: an empirical study in the Iraqi private banking sector. European Scientific Journal. Special edition vol.1.

Kurfi, S.A., Udin, N.M. \& Bahamman, S.M. (2017). The impact of intellectual capital on the financial performance of listed Nigerian food products companies. Journal of Accounting and Taxation. Vol. 9(11), pp. 147-160, DOI: 10.5897/JAT2017.0246

Luo, Y., Huang, Y. \& Wang, S. (2012) Guanxi and Organizational Performance: A Meta-Analysis. Management and Organization Review, 8(1), 139-172. https://doi.org/10.1111/j.17408784.2011.00273.x.

Mahapatro, B.B. (2013). Organization performance. Journal of Human resource managemnet, Vol. 12 Issue 1. Pp. 272- 279.

Manikas, I., \& Terry, L. A. (2009). A case study assessment of the operational performance of a multiple fresh produce distribution centre in the UK. British Food Journal, 111(5), 421-435.

Mathews, J. (2003). Competitive dynamics and economic learning: an extended resource-based view. Industrial and Corporate Change, Vol. 12 (1), 115-145.

Mulwa, M.N \& Weru, J.M. (2017). The Influence of Performance Management System on Employee Performance in Commercial Banks in Kitui Town, Kitui County, Kenya. Global journal of commerce and management perspective. Vol.9 (6):65-70. Retrieved from www.gifre.org

Nikolajevaite, M. \& Sabaityte, E. (2016). Relationship Between Employees' Competencies and Job Satisfaction: British and Lithuanian Employees. Journal of Psychology Research, Vol. 6, No. 11, 684-692. doi:10.17265/2159-5542/2016.11.007

Nwaiwu, J.N. \& Aliyu, A.S. (2018). Intellectual capital reporting and measures of financial performance of companies in Nigeria. International Journal of Advanced Academic Research | Financial Management | ISSN: 2488-9849 Vol. 4, Issue 2

Osei, A. J., \& Ackah, O. (2015). Employee'S Competency and Organizational Performance in the Pharmaceutical Industry. International Journal of Economics, Commerce and Management, 3(3), 19. http://ijecm.co.uk/.

Owoeye, I. \& Muathe, S.M. (2018). Competence-Enhancing Interventions and Organisational Performance: A Theoretical Review. Journal of Human Resource Management. Vol. 6, No. 2, pp. 67-77. doi: 10.11648/j.jhrm.20180602.14

Özçelik, G., \& Ferman, M. (2006). Competency approach to human resources management: Outcomes and contributions in a Turkish cultural context. Human Resource Development Review, 5(1), 72-91.

Panda, S. \& Jayarama R.K. (2016). A Study on effect of competence on organizational effectiveness in India. International Journal of Industrial Management. ISSN (Print): 2289-9286; e-ISSN: 0127-564x; Volume 2, pp. 1-6. 
Xiaosong Peng, D., Schroeder, R. G., \& Shah, R. (2011). Competitive priorities, plant improvement and innovation capabilities, and operational performance: A test of two forms of fit. International Journal of Operations \& Production Management, 31(5), 484-510. https://doi.org/10.1108/01443571111126292.

Ramayah, T., Samat, N., \& Lo, M. C. (2011). Market orientation, service quality and organizational performance in service organizations in Malaysia. Asia-Pacific Journal of Business Administration, 3(1), 8-27. https://doi.org/10.1108/175743211111116379.

Renyut, B.C., Modding, H.B., Bima, J. \& Sukmawati, S. (2017). The effect of organizational commitment, competence on Job satisfaction and employee's performance in Maluku Governor's Office. Journal of Business and Management. Volume 19, Issue 11. Ver.III. PP 18-29. DOI: 10.9790/487X-1911031829.

Rudmann, C. (2008). Entrepreneurial skills and their role in enhancing the relative independence of farmers. Retrieved September 13, 2019. from http://orgprints. Org.

Sarminah, S. (2013). Assessing the Contribution of Human Capital on Business Performance. International Journal of Trade, Economics and Finance, Vol. 4, No. 6. Pp 393-399. DOI: 10.7763/IJTEF. 2013.V4.324.

Sekaran, U. (2006). Metodologi penelitian untuk bisnis.

Smith, B., \& Morse, E. (2005). Entrepreneurial competencies: Literature review and best practices. Small Business Policy Branch, Industry Canada, Ottawa.

Tseng, S. M. (2010). The correlation between organizational culture and knowledge conversion on corporate performance. Journal of knowledge management, 14(2), 269-284. https://doi.org/10.1108/13673271011032409

Valmohammadi, C. \& Ahmadi, M. (2015). The impact of knowledge management practices on organizational performance: A balanced scorecard approach. Journal of Enterprise Information Management, 28(1), 131-159.

Wibowo, I. (2010). ManajemenKinerja. Penerbit: RajagrafindoPersada. Jakarta.

Yang, J. H., Fang, S. C., \& Huang, C. Y. (2017). The mediating role of competency on the relationship between training and task performance: Applied study in pharmacists. International Journal of Business Administration, 8(7), 16-24.

Zaim, H., Yaşar, M.F. \& Ünal, O.F. (2013). Analyzing the Effects of Individual Competencies on Performance: A Field Study in Services Industries in Turkey. Journal of Global Strategic Management, 7(2), 67-77. DOI: 10.20460/JGSM.2013715668.

Zamfir, A. (2013). A strategic management model for service organizations. Business Excellence and Management, 3(3), 55-60. 